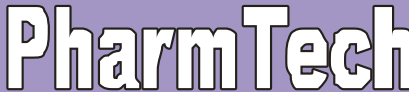

\section{International Journal of PharmTech Research}

\section{Pharmacognostical Investigation of Andrographis paniculata (Green Chiretta) and Crystallization of the Bioactive component Andrographolide}

\author{
Myrene R. Dsouza $^{1^{\star}}$, Sapam Athoibi ${ }^{1}$, Shashi Prabha ${ }^{1}$ \\ ${ }^{1}$ Department of Biochemistry, Mount Carmel College Autonomous, Bengaluru, India
}

\begin{abstract}
Andrographis paniculata (Family: Acanthaceae) is one the most commonly used ethno-medicinal plants in certain parts of Asia and European countries. The phytochemical analysis of the leaves of $A$. paniculata in aqueous, methanolic, ethanolic, hydromethanolic (1:1) and hydroethanolic (1:1) extracts revealed the presence of carbohydrates, amino acid, alkaloids, saponins, tannins, flavonoids, terpenoids, glycosides, xanthoproteins and phenols. The total phenolic, flavonoid contents and FRAP values were found to be highest in the hydromethanolic extract i.e., $0.23 \pm 0.008 \mathrm{mg} \mathrm{GAE} / \mathrm{g}$ of FWt, $0.031 \pm 0.00 \mathrm{mg} \mathrm{QE} / \mathrm{g} \mathrm{FWt}$ and1.261 $\pm 0.03 \mathrm{mM} \mathrm{FeSO}$ respectively. Invitro antioxidant capacity by linear regression analysis was measured by assaying DPPH radical and $\mathrm{H}_{2} \mathrm{O}_{2}$ scavenging capacities. The respective $\mathrm{IC}_{50}$ values of the hydromethanolic extract of the plant were found to be 86.51 $\mu \mathrm{g} / \mathrm{ml}$ and $298.27 \mu \mathrm{g} / \mathrm{ml}$. The $\mathrm{IC}_{50}$ values for in vitro anti-inflammatory activities were evaluated by heat induced protein denaturation $\left(\mathrm{IC}_{50}\right.$ diclofenac $=574.06 \mu \mathrm{g} / \mathrm{ml}, \mathrm{IC}_{50} \mathrm{APE}=179.7$ $\mu \mathrm{g} / \mathrm{ml})$ and $\mathrm{RBC}$ membrane stabilization assay $\left(\mathrm{IC}_{50 \text { diclofenac }}=337.64 \mu \mathrm{g} / \mathrm{ml}, \mathrm{IC}_{50 \mathrm{APE}}=143.07\right.$ $\mu \mathrm{g} / \mathrm{ml})$. The $\mathrm{IC}_{50}$ values for in vitro anti-diabetic activities were evaluated by $\alpha$-amylase inhibition $\left(\mathrm{IC}_{50}\right.$ acarbose $\left.=379.71 \mu \mathrm{g} / \mathrm{ml}, \mathrm{IC}_{50 \mathrm{APE}}=328.54 \mu \mathrm{g} / \mathrm{ml}\right)$. In addition, glucose diffusion was also monitored. Antimicrobial activity of the extracts was studied against common pathogens using well diffusion method. The purification of Andrographolide was carried out using different physical separation techniques such as extraction and crystallization followed by drying.
\end{abstract}

Keywords: A. paniculata, andrographolide, anti-inflammatory, antioxidant, crystallization, hypoglycemia.

\section{Introduction}

The past two decade have shown rapidly rising interest in medicinal plants for their use in herbal products as natural cosmetics and also for self-medication often rarely without a prescription. In addition to its use in pharmaceuticals, a gradually growing area is the incorporation of bioactive compounds into nutraceuticals for diet supplementation. One such medicinal plant is Andrographis paniculata (Family:

Myrene R. Dsouza et al /International Journal of PharmTech Research, 2020,13(2): 40-50. 
Acanthaceae), commonly known as kalmegh (King of Bitters), widely used in Indian systems of medicine in the treatment of many diseases such as cancer, diabetes, high blood pressure, ulcer, leprosy, bronchitis, skin disease, flatulence, influenza, dysentery and dyspepsia ${ }^{1-4}$. It also acts as an antidote against poisons from snakes and insects ${ }^{5}$. Pharmacological and clinical studies suggest possible beneficial effects in diseases like cancer and HIV infections ${ }^{6}$. In Traditional Chinese Medicine, A. paniculata is regarded as a bitter and 'cold property' herb used to treat 'hot' conditions such as acute infections and fever, including throat infection, pneumonia, tonsillitis, dysentery, gastroenteritis and pyelonephritis ${ }^{7,8}$. It is used in Malaysian folk medicine for treating diabetes and hypertension ${ }^{9,10}$.

The leaf extract of $A$. paniculata has demonstrated protection against $\mathrm{CCl}_{4}$-induced hepatotoxicity and $\mathrm{CCl}_{4}$-induced microsomal lipid peroxidation ${ }^{11,12}$. The leaf extract has been used in the formulation of Indian herbal proprietary preparations (Ex., Kalmeghasava and Kalmeghnamay Haub) for the treatment of liver ailments ${ }^{13,14}$. It has been reported that there are four lactones in A. paniculata namely 14-deoxyandrographolide, andrographolide, neoandrographolide, $\mathrm{C}-3-\mathrm{O}$ glucoside derivative of the main constituent andrographolide and 14-deoxy-11,12-di-dehydro-andrographolide ${ }^{5,13}$. Treatment of diseases requires understanding multiple targets of conventional drug therapy resulting polypharmacy. Thus, it is important to understand multiple potential targets and mechanisms of plant constituents derived from plants. Traditional medicines are extensively researched for their ability to treat inflammation. Evidences suggests that use of omic methods, including genomics, transcriptomics, epigenomics, proteomics, metabolomics, etc., to reanalyze traditional medicines will lead to new insights and offer opportunities for new types of medicine.

\section{Materials and Methods}

Sample collection, phytochemical screening and fluorescence analysis: Andrographis paniculata plants were collected from a medicinal plant farm in Imphal, Manipur in the month of July and authenticated. The leaves were washed in tap water to remove dirt, rinsed in distilled water and then sun dried. The leaves were ground into fine powder and stored in air tight bottles at $4{ }^{\circ} \mathrm{C}$ for further analysis. In the first set of experiments, the extraction was performed using different systems at 5\% (w/v): distilled water (WE), methanol (ME), ethanol (EE), and 50\% methanol (HME) and 50\% ethanol (HEE) and then subjected to phytochemical screening as per the standard methodology ${ }^{15,16}$. Fluorescence characteristics of the powdered seed with different chemicals were observed in daylight and ultraviolet light ${ }^{17}$.

\section{Determination of Antioxidant activity}

Total phenolic, flavonoid and FRAP activity: Total phenolic contents were estimated according to the spectrophotometric method using gallic acid as standard ${ }^{18}$ and expressed in terms of gallic acid equivalent (mg of GAE/g of tissue). Aluminum chloride colorimetric method was used for determination of total flavonoids ${ }^{19}$ and expressed in terms of quercetin equivalent ( $\mathrm{mg}$ of $\mathrm{QE} / \mathrm{g}$ of tissue). The ferric ions $\left(\mathrm{Fe}^{3+}\right)$ reducing antioxidant power (FRAP) method was used to measure the reducing capacity of plant extracts ${ }^{20}$.

DPPH radical scavenging activity: Procedure of $\mathrm{Braca}^{21}$ was used for determination of DPPH scavenging capacity of various fractions. A stock solution of ascorbic acid $(1000 \mu \mathrm{g} / \mathrm{ml})$ was diluted ranging from 10-100 $\mu \mathrm{g} / \mathrm{ml}$. $0.1 \mathrm{ml}$ solution from different dilutions was pipetted out in respective tubes. The volume in each tube was made up to $3 \mathrm{ml}$ with DPPH $(20 \mu \mathrm{g} / \mathrm{ml})$. The test tubes were incubated for $10 \mathrm{~min}$ at room temperature. The contents of each tube were mixed well and the absorbance was measured at $517 \mathrm{~nm}$ against a blank. A control (DPPH solution alone) was prepared. The percentage inhibition of DPPH by the samples was calculated as follows:

$$
\text { Scavenging effect }(\%)=\frac{O D \text { of control }- \text { OD of sample }}{O D \text { of control }} \times 100
$$

Hydrogen peroxide scavenging activity: The estimation of hydrogen peroxide scavenging activity of the extracts was determined by using the method of $\mathrm{Ruch}^{22}$ with minor modification. Solution of hydrogen peroxide $(45 \mathrm{mM})$ was prepared using phosphate buffer $(1 \mathrm{M} \mathrm{pH} 7.4)$. The sample extracts of different concentration 
$(100-500 \mu \mathrm{g} / \mathrm{ml})$ was added to hydrogen peroxide solution and incubated for $10 \mathrm{~min}$. Absorbance was read at $230 \mathrm{~nm}$ against blank solution containing phosphate buffer only. Ascorbic acid was used as standard. The concentration of $\mathrm{H}_{2} \mathrm{O}_{2}(\mathrm{mM})$ in the assay medium was determined using a standard curve $(\mathrm{y}=0.1245 \mathrm{x}+$ $\left.0.3319 ; \mathrm{R}^{2}=0.9365\right) . \mathrm{H}_{2} \mathrm{O}_{2}$ scavenging ability was expressed as $\mathrm{IC}_{50}$. The scavenging effect was calculated as follows:

$$
\text { Scavenging effect }(\%)=\frac{O D \text { of control }- \text { OD of sample }}{O D \text { of control }} \times 100
$$

\title{
Determination of In vitro Anti-inflammatory activity
}

Inhibition of heat induced protein denaturation: The anti-inflammatory activity was determined using inhibition of albumin denaturation method with slight modifications ${ }^{23}$. The extracts of different concentration $(100-500 \mu \mathrm{g} / \mathrm{ml})$ were treated with $1 \%$ aqueous solution of BSA (bovine serum albumin). The $\mathrm{pH}$ was maintained by the addition of few drops of $1 \mathrm{~N}$ hydrochloric acid. The sample extracts were incubated at $37^{\circ} \mathrm{C}$ for $15 \mathrm{~min}$ and then heated at $51^{\circ} \mathrm{C}$ for $15 \mathrm{~min}$. The extracts were cooled, and its turbidity was measured at 660 $\mathrm{nm}$. Aspirin was used as standard. The percentage inhibition of protein denaturation was calculated from the following equation.

$$
\text { Inhibition }(\%)=\frac{O D \text { of control }- \text { OD of sample }}{O D \text { of control }} \times 100
$$

hRBC membrane stabilization activity: The test was performed using the method of Azeem ${ }^{24}$. Extracts at different concentration $(100-500 \mu \mathrm{g} / \mathrm{ml})$ was mixed with $1 \mathrm{ml}$ of phosphate buffer, $2 \mathrm{ml}$ of hyposaline and $0.5 \mathrm{ml}$ of hRBC suspension. Diclofenac sodium was used as the standard drug. Control was prepared using phosphate buffer, hyposaline and $\mathrm{hRBC}$ suspension without the sample extracts. The mixtures were incubated at $37{ }^{\circ} \mathrm{C}$ for $30 \mathrm{~min}$ and centrifuged at $3000 \mathrm{rpm}$. The supernatant was decanted and the haemoglobin content was estimated spectroscopically at $560 \mathrm{~nm}$. The percentage haemolysis was estimated by assuming the haemolysis produced in the control as $100 \%$. the percentage inhibition of the protein denaturation was calculated using the equation. $\mathrm{IC}_{50}$ was calculated from $\mathrm{y}=0.118 \mathrm{x}+33.117, \mathrm{R}^{2}=0.5126$.

$$
\text { Inhibition }(\%)=\frac{O D \text { of control }- \text { OD of sample }}{\text { OD of control }} \times 100
$$

\section{Determination of in vitro anti-diabetic activity}

In vitro inhibition of glucose diffusion activity: The inhibition of glucose movement by the methanolic and ethanolic extracts of $A$. paniculata was determined by using the method proposed by Edwards ${ }^{25}$. The method involved the use of a sealed dialysis into which $7 \mathrm{ml}$ of a solution of glucose $(0.22 \mathrm{M})$ and sodium chloride $(0.15 \mathrm{M})$ was introduced and the appearance of glucose in the external solution was measured. The model used in the present experiment consisted of a dialysis tube into which $2 \mathrm{ml}$ of plant extract in $1 \% \mathrm{CMC}$ and $1 \mathrm{ml}$ of $0.15 \mathrm{M} \mathrm{NaCl}$ containing $0.22 \mathrm{M} \mathrm{D}$-glucose was added. The dialysis tube was sealed at each end placed in a 50 $\mathrm{ml}$ beaker containing $45 \mathrm{ml}$ of $0.15 \mathrm{M} \mathrm{NaCl}$. The tubes were placed on an orbital shaker and kept at room temperature.

\begin{abstract}
Alpha-amylase inhibition assay: Alpha amylase activity can be measured by the determination of reducing groups arising from hydrolysis of soluble starch by isolated pancreatic $\alpha$-amylase. The reduction of 3,5 dinitrosalicylic acid to nitro-aminosalicylic acid produces a red colour, which was measured spectrophotometrically at $540 \mathrm{~nm}$. Inhibition of starch hydrolysis by an $\alpha$-amylase inhibitor results in diminished absorbance at $540 \mathrm{~nm}$ compared to control and standard drug (Acarbose). $1 \mathrm{ml}$ of the plant extract was pre-incubated with $1 \mathrm{ml}$ of the enzyme solution for $30 \mathrm{~min}$ and then $1 \mathrm{ml}$ of $1 \% \mathrm{w} / \mathrm{v}$ starch solution was added. This was further incubated at $37{ }^{\circ} \mathrm{C}$ for $10 \mathrm{~min}$. The reaction was arrested by heating the contents with 1 $\mathrm{ml}$ dinitrosalicylic acid reagent in boiling water bath for $5 \mathrm{~min}$. Blank containing only the buffer solution was
\end{abstract}


used. The absorbance was measured at $540 \mathrm{~nm}$ against a blank comprising of only buffer solution. Acarbose was used as positive control at the concentration of $500 \mu \mathrm{g} / \mathrm{ml}$.

$$
\text { Inhibition }(\%)=\frac{O D \text { of control }- \text { OD of sample }}{O D \text { of control }} \times 100
$$

\section{Extraction and Purification of Andrographolide}

Solid-Liquid Extraction: As HME gave the best results for phytochemical screening, this extract was used for isolation of the bioactive component, Andrographolide. The leaf sample (50 g) was macerated overnight in 50\% methanol and filtered. The marc was packed into a Soxhlet apparatus and extracted with the solvent (10 cycles).

Enrichment of the Extract: The leaf extract of A. paniculata is rich in colouring pigments that affect the later phases of extraction and also reduces the visual quality of the final product; hence it was treated with different percentages of activated charcoal (5-25\%) and refluxed for $20 \mathrm{~min}$. The extract was then filtered and the residual charcoal was mixed with 50\% methanol and refluxed again for $10 \mathrm{~min}$. The filtrates were then combined and concentrated. The total content of chlorophyll was estimated by taking the absorbance at 646 and $662 \mathrm{~nm}^{26,27}$. The extract obtained was used for further study.

Purification of Andrographolide by crystallization: The extracts were collected separately and the solvent removed under vacuum. The dark green crystalline mass obtained was washed, separately, with toluene several times until most of the colouring matter was removed from the residue. Then the toluene was completely removed from the residue. The crystalline material left behind (yield 1.7-1.8 g) was dissolved in hot methanol and cooled in a refrigerator for crystallization. The process was repeated several times until colourless plates of constant melting point of $230-231^{\circ} \mathrm{C}$ were obtained.

Purity test of the isolated Andrographolide: The purity of the compound isolated was checked by carrying out TLC in different solvent systems ${ }^{28,29}$ along with reference standard andrographolide (obtained from Regional Research Laboratory, Bengaluru, India).

\section{Results and Discussion}

Natural products have been a rich source of possible therapeutics since they provide a host of bioactive molecules, most of which probably evolved as chemical defenses against predation and infection. They are the basis of many standard drugs used in modern medicine. In addition to having adverse side effects on humans, pathogens and insects develop resistance on regular use of synthetic drugs. The screening of plants extracts for anti-inflammatory activity have shown that higher plants represent potential source of new anti-infective agents. The inflammatory response involves a complex array of enzyme activation, release of mediators, cell migration and extravasation, tissue breakdown and repair aimed at host defense and usually activated under most disease conditions. These reactions in an inflammatory response cascade are therapeutic targets which antiinflammatory agents including medicinal plants interfere with, to suppress exacerbated inflammatory responses. In the recent years, there has been a more intensified search for anti-inflammatory and anti-diabetic agents especially from the documented array of medicinal plants that have proven to suppress relevant aspects of the inflammatory cascade that trigger various disease processes. This present study was carried out to assess the validity of the folkloric uses of Andrographis paniculata in the management and treatment of inflammatory disorders. In the present research, extracts of A. paniculata was evaluated for its antioxidant, anti-inflammatory and anti-diabetic properties.

Phytochemical screening and fluorescence analysis: Phytochemicals are the chemicals which are produced by plants through primary or secondary metabolism. They possess biological activity in vivo and play a significant role in plant growth and defense against competitor, pathogen and predator. The photochemical screening of the leaves extracts of $A$. paniculata was investigated in aqueous (WE), methanol (ME), ethanol (EE), methanol: water (HME) and ethanol: water (HEE). The investigation of the phytochemical screening 
results revealed the presence of alkaloids, glycosides, saponin, terpenoids, phenol, flavonoid, carbohydrates, protein and amino acids in variable concentrations with best results documented by HME and HEE (Table 1).

Table 1: Phytochemical screening for Andrographis paniculata.

\begin{tabular}{|l|l|c|c|c|c|c|}
\hline SINo. & Phytochemical analyzed & \multicolumn{5}{|c|}{ Result } \\
\cline { 3 - 7 } & & HE & ME & HME & EE & HEE \\
\hline 1 & Alkaloids & +++ & + & +++ & ++ & ++ \\
\hline 2 & Glycosides & ++ & - & + & - & + \\
\hline 3 & Saponin & + & - & + & - & + \\
\hline 4 & Terpenoids & ++ & + & ++ & ++ & ++ \\
\hline 5 & Phenols & +++ & ++ & +++ & ++ & ++ \\
\hline 6 & Flavonoids & ++ & + & +++ & +++ & +++ \\
\hline 7 & Protein and amino acid & ++ & - & +++ & ++ & ++ \\
\hline 8 & Carbohydrate & ++ & ++ & +++ & + & + \\
\hline
\end{tabular}

-indicate absence, + denotes average, ++ means abundance, +++ means more abundance of phytochemicals.

Fluorescence analysis is one of the pharmacognostic procedures useful in the identification of genuine sample and recognizing contaminants. The fluorescent analysis of powdered leaf sample of A. paniculata with different chemical agents were observed under visible and UV light (Table 2).

Table 2: Fluorescence analysis of Andrographis paniculata.

$\begin{array}{ll}\text { SI } & \text { Experiment } \\ 1 & \text { Distilled Water } \\ 2 & \text { Acetone } \\ 3 & \text { Ethanol } \\ 4 & \text { Benzene } \\ 5 & \text { Chloroform } \\ 6 & \text { Diethyl ether } \\ 7 & \text { Methanol } \\ 8 & \text { Glacial acetic acid } \\ 9 & \text { Conc. } \mathrm{H}_{2} \mathrm{SO}_{4} \\ 10 & \mathrm{HCl}_{1} \\ 11 & \mathrm{HNO}_{3} \\ 12 & 5 \% \mathrm{FeCl}_{3} \\ 13 & 5 \% \mathrm{I}_{2} \\ 14 & 1 \mathrm{~N} \mathrm{NaOH} \\ 15 & 1 \mathrm{~N} \mathrm{NaOH}+\text { Methanol } \\ 16 & \text { Picric acid }\end{array}$

$\begin{array}{ll}\text { UV light (365) } & \text { Visible light } \\ \text { Dark green } & \text { Green } \\ \text { Orange } & \text { Dark green } \\ \text { Orange-green } & \text { Green } \\ \text { Yellowish-Orange } & \text { Dark green } \\ \text { Yellow-Orange } & \text { Light green } \\ \text { Orange } & \text { Dark green } \\ \text { Orange-Green } & \text { Light green } \\ \text { Orange } & \text { Brown } \\ \text { Green } & \text { Reddish brown } \\ \text { Black } & \text { Greenish brown } \\ \text { Black } & \text { Brown } \\ \text { Black } & \text { Brown } \\ \text { Brown-Black } & \text { Brown } \\ \text { Fluorescence green } & \text { Greenish brown } \\ \text { Fluorescence green } & \text { Brown } \\ \text { Dark brown } & \text { Dark green }\end{array}$

\section{Antioxidant activity:}

Plant phenolics play an important role in regulating carbohydrate and lipid metabolism, weaken hyperglycemia, dyslipidemia and insulin resistance, invigorate insulin discharge, enhance fat tissue digestion and ease oxidative stress $^{30}$. Total phenols are also attributed with anti-allergenic, anti-artherogenic, anti-inflammatory, antimicrobial, antioxidant, anti-thrombotic, cardioprotective and vasodilatory effects ${ }^{30,31,32}$. The total phenolic content calculated using the standard curve of gallic acid $\left(y=0.00005 x+0.282, R^{2}=0.4022\right)$ was found to be $0.23 \pm 0.008 \mathrm{mg} \mathrm{GAE} / \mathrm{g}$ of fresh weight tissue respectively (Table 3). Flavonoids, the most common secondary metabolite provides health benefits through their antioxidant activity. Their levels as estimated 
spectrophotometrically using a standard curve of quercetin $\left(y=0.0006 x+0.0094, R^{2}=0.955\right)$ was found to be $0.031 \pm 0.00 \mathrm{mg} / \mathrm{g}$ fresh weight tissue (Table 3). The antioxidant potentials of the HME of A. paniculata was determined from their ability to reduce ferric tripyridyltriazine ( $\mathrm{Fe}^{3+}$-TPTZ) complex to a coloured ferrous tripyridyltriazine $\left(\mathrm{Fe}^{2+}-\mathrm{TPTZ}\right)$. The results showed that FRAP values were higher in methanol:water extracts $\left(1.261 \pm 0.03 \mathrm{mM} \mathrm{FeSO}_{4}\right)$ compared to the standard i.e., ascorbic acid (Table 3).

Table 3: Quantitative analysis of total phenols, total flavonoids and FRAP activity of HME of $A$. paniculata leaf.

\begin{tabular}{|c|c|c|}
\hline $\begin{array}{c}\text { Total Phenols } \\
\text { (mg GAE/g Fwt) }\end{array}$ & $\begin{array}{c}\text { Total Flavonoids } \\
\text { (mg QE/g Fwt) }\end{array}$ & $\begin{array}{c}\text { FRAP activity } \\
\text { (mM FeSO4) }\end{array}$ \\
\hline $0.23 \pm 0.008$ & $0.031 \pm 0.00$ & $1.261 \pm 0.03$ \\
\hline
\end{tabular}

All values are represented as mean $\pm \mathrm{SD}(\mathrm{n}=3)$. GAE - Gallic acid equivalents; $\mathrm{QE}-$ Quercetin equivalents.

The total antioxidant activity of the various extracts was determined by calculating the percentage inhibition of various extracts against the standard ascorbic acid $\left(\mathrm{y}=0.3459 \mathrm{x}+7.659, \mathrm{R}^{2}=0.9316\right)$. At a concentration of $500 \mu \mathrm{g} / \mathrm{ml}$, A paniculata exhibited $78.4 \%$ inhibition against DPPH with an $\mathrm{IC}_{50}$ of 86.51 $\mu \mathrm{g} / \mathrm{ml}$ (Table 4). The results demonstrate that A. paniculata has the ability of significantly decreasing in vitro DPPH radical levels. There is high probability that these activities arise due to the occurrence of polyphenolic compounds such as tocopherols, flavonoids and other organic acids ${ }^{33}$ that serve to quench oxygen radicals.

Hydrogen peroxide $\left(\mathrm{H}_{2} \mathrm{O}_{2}\right)$ is generated in vivo, by peroxisomes, by several oxidative enzymes and by dismutation of superoxide radical, catalyzed by superoxide dismutase. $\mathrm{H}_{2} \mathrm{O}_{2}$ acts as a messenger molecule in the synthesis and activation of inflammatory mediators via its reduction product $\mathrm{OH} \bullet{ }^{34} \cdot \mathrm{H}_{2} \mathrm{O}_{2}$ scavenging assay was used to monitor the decrease in the absorbance of $\mathrm{H}_{2} \mathrm{O}_{2}$ upon its oxidation. The percentage inhibition of $\mathrm{HME}$ of $A$. paniculata at $500 \mu \mathrm{g} / \mathrm{ml}$ was found to be $66.14 \%$ at $500 \mu \mathrm{g} / \mathrm{ml}$ with an $\mathrm{IC}_{50}$ value of $298.27 \mu \mathrm{g} / \mathrm{ml}$ (Table 4). The ability of the extract to scavenge $\mathrm{H}_{2} \mathrm{O}_{2}$ is indicative of high antioxidant potential. Antioxidant activity due to the presence of hydroxyl group possessing scavenging activity has been noted by neutralizing or absorbing superoxide anion, peroxy radicals by quenching or decomposing them ${ }^{35,36}$.

\section{Anti-inflammatory activity:}

Inflammation said to be a complex physiopathological response to different stimuli. The process involves the activity of mediators such as neutrophil derived free radical, reactive oxygen species (ROS), nitric oxide (NO), prostaglandins and cytokines (Ghosh,1998) which upon over production causes tissue injury by damaging macromolecules and lipid peroxidation of membrane. Tissue damage is hence an important indicator of pathogenesis of many inflammatory diseases. Thus, free radicals are important mediators that provoke or sustain inflammatory processes and consequently, their neutralization by antioxidants and radical scavengers can attenuate inflammation ${ }^{37}$.

One cause of inflammation is the denaturation of proteins resulting in the loss of its biological function. As part of the investigation on the mechanism of A. paniculata ability to inhibit protein denaturation, albumin was subjected to heat denaturation in the presence of the extract. It was found that at a concentration of 500 $\mu \mathrm{g} / \mathrm{ml}$, A. paniculata exhibited $90.1 \%$ inhibition while Diclofenac, a standard anti-inflammatory drug showed maximum inhibition of $82.6 \%$. The $\mathrm{IC}_{50}$ was found to be $179.7 \mu \mathrm{g} / \mathrm{ml}$ and $574.06 \mu \mathrm{g} / \mathrm{ml}$ respectively (Table 4). 
Table 4: Evaluation of in vitro antioxidant and anti-inflammatory activities of hydromethanolic $A$. paniculata leaf extracts. Linear regression analysis was used to calculate $\mathrm{IC}_{50}$ value.

\section{DPPH scavenging activity}

Conc Control HME

\section{\% Inhibition}

$$
\underset{\text { activity }}{\mathrm{H}_{2} \mathrm{O}_{2} \text { scavenging }}
$$

\section{Heat induced protein denaturation}

Control

67.4

68.5

$200 \quad 49.2$

$300 \quad 70.2$

$400 \quad 80.6$

$500 \quad 82.2$

$\mathrm{IC}_{50} \quad 122.4$

\section{3}

70.2

78.4

86.51
Control HME

8.04

24.4

48.9

50.5

56.7

400.55

\section{2}

50.2

50.3

59.8

66.1

298.27
23.2

45.1

53.6

65.2

82.6

$\mathbf{5 7 4 . 0 6}$

\begin{tabular}{l} 
HME \\
81.5 \\
84.7 \\
87.3 \\
88.5 \\
90.1 \\
\hline $\mathbf{1 7 9 . 7 2}$
\end{tabular}

\section{RBC membrane stabilization}

Control HME

$36.13 \quad 72.2$

$47.02 \quad 73.12$

$44.96 \quad 74.53$

$54.62 \quad 74.53$

$62.42 \quad 81.1$

337.64 143.07

Membrane stabilization is a process in which the integrity of the erythrocyte and lysozyme membranes is maintained by anti-inflammatory drugs or likely drug candidates that inhibit the release of enzymes involved in the activation of inflammatory mediators which may affect the surrounding tissue leading to inflammation ${ }^{38}$. The in vitro mammalian erythrocyte hemolysis is generally used for investigating the anti-inflammatory activity of the drugs due to absence of nuclei or internal membranes ${ }^{39}$. The function and structure of the erythrocyte membrane is similar to that of the lysosomal membrane and hence the stabilizing effect produced by the drugs on these membranes might be similar ${ }^{40}$. The $\%$ inhibition was calculated and compared with standard Diclofenac. It was found that the buffered extract of A. paniculata at a concentration of $500 \mu \mathrm{g} / \mathrm{ml}$ showed maximum inhibition of $62.42 \%$ with an $\mathrm{IC}_{50}$ value of $143.07 \mu \mathrm{g} / \mathrm{ml}$ (Table 4).

In vitro hypoglycemic activity: Diabetes mellitus is a metabolic disorder characterized by hyperglycaemia and alterations in carbohydrate, lipid, and protein metabolism, associated with absolute or relative deficiencies in insulin secretion and/or insulin action ${ }^{41}$. The high prevalence of diabetes and the associated long-term complications has led to a search for hypoglycaemic agents derived especially from medicinal plants ${ }^{42}$.

In vitro glucose diffusion inhibitory assay: The cells present in the human body require energy to perform certain metabolic functions that sustain life. This energy is provided by glucose, a simple carbohydrate that acts as a primary fuel in brain, muscles and several other organs. Abnormal level of glucose in the body might lead to certain complication which could be life threatening. Thus, controlled regulation in terms of glucose uptake across the cell membrane ensures proper regulation of glucose homeostasis. The study of glucose uptake by the body cells is very important as it helps in the identification of certain diseases and metabolic disorders such as myocardial ischemia, diabetes mellitus and cancer ${ }^{43}$. In this test, hydromethanolic and hydroethanolic extracts of A. paniculata was used to determine the possible anti-diabetic activity (Table 5). The result revealed that both extracts exhibited poor uptake of glucose thereby showing very less anti-diabetic property.

Table 5: Effect of hydromethanolic extract of T. arjuna bark on glucose diffusion compared to the control Metronidazole.

\begin{tabular}{|c|c|c|c|c|c|}
\hline \multirow{2}{*}{ Sample } & \multicolumn{5}{|c|}{ Glucose content in dialysate $\mathbf{( m M}$ ) } \\
\cline { 2 - 6 } & $\mathbf{6 0} \mathbf{~ m i n}$ & $\mathbf{1 2 0} \mathbf{~ m i n}$ & $\mathbf{3 0 0} \mathbf{~ m i n}$ & $\mathbf{4 8 0} \mathbf{~ m i n}$ & $\mathbf{7 2 0} \mathbf{~ m i n}$ \\
\hline Control & $0.038 \pm 0.01$ & $0.028 \pm 0.008$ & $0.057 \pm 0.013$ & $0.155 \pm 0.042$ & $0.63 \pm 0.18$ \\
\hline A. paniculata (HME) & $0.31 \pm 0.007$ & $0.349 \pm 0.01$ & $0.639 \pm 0.011$ & $0.511 \pm 0.003$ & $1.225 \pm 0.22$ \\
\hline A. paniculata (HEE) & $0.221 \pm 0.005$ & $0.278 \pm 0.003$ & $0.325 \pm 0.00$ & $0.240 \pm 0.00$ & $0.982 \pm 0.33$ \\
\hline
\end{tabular}




\section{Alpha-amylase inhibition assay:}

$\alpha$-amylase, an enzyme found in pancreatic juice and saliva breaks down starch into glucose and maltose ${ }^{44}$ thereby leading to hyperglycemia. Inhibitors of $\alpha$-amylase has the ability to delay the hydrolysis of polysaccharides in the small intestine and diminishes the spike in blood glucose ${ }^{45}$. This assay was conducted to determine the ability of the alcoholic extracts of A. paniculata to inhibit $\alpha$-amylase activity (Table 5). Acarbose was used as a standard anti-diabetic drug. It was observed that the alcoholic extracts of $A$. paniculata exhibited better anti-diabetic activity compared to the acarbose standard (Table 6). The $\mathrm{IC}_{50}$ of A. paniculata and acarbose were found to be $328.54 \mu \mathrm{g} / \mathrm{ml}\left(\mathrm{y}=0.137 \mathrm{x}+1.1043, \mathrm{R}^{2}=0.9505\right)$ and $379.71 \mu \mathrm{g} / \mathrm{ml} \quad(\mathrm{y}=0.1238 \mathrm{x}+9.325$, $\mathrm{R}^{2}=0.8757$ ) respectively. This indicates that the leaves of the medicinal plant A. paniculata could be a good alternative to other medicines used for treating diabetes.

Table 6: $\alpha$-amylase inhibition by alcoholic extracts $A$. paniculata and $E$. foetidum.

\begin{tabular}{|c|c|c|c|}
\hline \multicolumn{2}{|c|}{ Control } & \multicolumn{2}{c|}{ A. paniculata } \\
\hline \multirow{2}{*}{$\begin{array}{c}\text { Conc. } \\
(\boldsymbol{\mu g} / \mathbf{m l})\end{array}$} & \% inhibition & \%ME & HEE \\
\cline { 3 - 4 } & 15.5 & 22.22 & 8.33 \\
\hline 100 & 25.2 & 30.62 & 36.75 \\
\hline 200 & 36.11 & 44.44 & 48 \\
\hline 300 & 54.6 & 59.72 & 51.38 \\
\hline 400 & 66.66 & 65.27 & 68.05 \\
\hline 500 & $\mathbf{3 7 9 . 7 1}$ & $\mathbf{3 2 8 . 5 4}$ & $\mathbf{3 5 6 . 9}$ \\
\hline $\mathbf{I C}_{\mathbf{5 0}}$ & & & \\
\hline
\end{tabular}

Anti - microbial activity: The development of bacterial resistance to currently available antibiotics has made it necessary to search for new antibacterial agents. Extracts of certain plants has been used to determine the antimicrobial activity against certain bacterial strains. The present study was carried out to determine the antimicrobial activity of various extracts of A. paniculata. The values obtained were compared with the control and it was found that the extract was potent against gram negative and gram positive bacteria selected (Table 7). The presence of bioactive compound in A. paniculata possess anti-microbial activity which can be isolated for the development of new anti-fungal, anti-malarial, anti-bacterial etc. However, further work is necessary to isolate and purify the compounds in these extracts, which will allow the scientific community to recommend their utilization as an accessible alternative to synthetic antibiotics.

Table 7: Antimicrobial activity of extract of $A$. paniculata. The zone of inhibition is expressed in $\mathbf{m m}$.

\begin{tabular}{|l|l|c|c|c|c|c|}
\hline Sample & Extract & E. coli & B. subtilis & K. pneumoniae & P. aeruginosa & S. aureus \\
\hline \multirow{4}{*}{ A. paniculata } & EE & 9 & 10 & 13 & 11 & 9 \\
\cline { 2 - 7 } & ME & 5 & 8 & 11 & 12 & 8 \\
\cline { 2 - 7 } & HEE & 2 & 9 & 12 & 7 & 8 \\
\cline { 2 - 7 } & HME & 2 & 7 & 9 & 7 & 6 \\
\hline \multirow{2}{*}{ Control } & Cipro & 13 & 15 & 20 & 15 & 13 \\
\hline
\end{tabular}

All values are represented as mean $\pm \mathrm{SD}(\mathrm{n}=3)$.

\section{Isolation of Andrographolide:}

Isolation of the pure compound was achieved by repeated washing off of the green colour from the crystalline matter with toluene. This was followed by repeated recrystallization from methanol and final washing of the crystals with cold methanol. The purity of the sample at every stage of recrystallization was monitored through TLC. The solvent system best suited for pure andrographolide was found to be chloroform:methanol:ethyl acetate $(8: 1.5: 1)(\mathrm{Rf}=0.65)$. 


\section{Purity of the isolated Andrographolide:}

The crude leaf possessed a deep green colouration due to the presence of chlorophyll and flavonoids. The presence of chlorophyll effects the purification process and therefore the purity of the andrographolide. To rid the sample of chlorophyll and other impurities, an economical method using activated charcoal as adsorbent was selected $^{46}$. Prior to its use, the charcoal is washed with water to remove possible contamination with iron, acid, ash, and water-soluble impurities. The crude green extract was then treated with different percentages of activated charcoal (5-20\%) in order to remove substantial amount of chlorophyll. The pigment content reduces by about $85 \%$ in terms of chlorophyll by the process of crystallization. For andrographolide crystallization, methanol was used in the medium (Table 8 ). The crystals have a very good solubility, they can be used in the preparation of herbal formulations or medicines under approval of GRAS (Generally Recognized as Safe).

Table 8: Isolation of Andrographolide after Crystallization and Re-crystallization

\begin{tabular}{|l|c|c|c|}
\hline Crystals procured from different operations & Melting point & Andrographolide (\%) & $\begin{array}{l}\text { Recovery or } \\
\text { overall } \\
\text { yield (\%) }\end{array}$ \\
\hline $\begin{array}{l}\text { Crystallization by evaporation followed by } \\
\text { cooling }\end{array}$ & $220-230$ & 93.67 & 94.2 \\
\hline Recrystallization & $226-230$ & 96.0 & 92.59 \\
\hline
\end{tabular}

The purity of andrographolide crystals isolated was established by TLC of the isolated sample, carried out in different solvent systems ${ }^{47,48}$. A single spot with $\mathrm{Rf}$ value ranging from $0.2-0.9$ was obtained corresponding to the solvent systems used: (i) chloroform:methanol:ethyl acetate $(8: 1.5: 1)-\mathrm{Rf}=0.65$; (ii) chloroform:methanol $(9: 1)-\mathrm{Rf}=0.9$; (iii) chloroform:ethyl acetate $(6: 4)-\mathrm{Rf}=0.2$.

\section{Conclusion:}

The presence of various bio active metabolites was indicated by phytochemical screening (Table 1) confirming that the hydromethanolic extract of A. paniculata is a potent source for modern drugs. In addition, the extract was found to possesses potential antioxidant, anti-inflammatory, anti-diabetic and anti-microbial activities. Ethanomedicinal use of $A$. paniculata as a useful remedy in various disorders could possibly be because of its excellent anti-inflammatory and antioxidant potential. The hypoglycemic activity mediated by decreasing glucose diffusion rate is suggestive of its anti-diabetic role. However, these results should be confirmed by in vivo models and clinical trials for their effective utilization as therapeutic agents. The extraction of andrographolide from A. paniculata using methanol was performed followed by extract clarification using activated charcoal treatment. Evaporation followed by cooling crystallization yielded the compound in the range of 90-96\%. Taking great concern of the useful benefits of the plant, it can be advocated as a safe, highly important medicinal plant for mankind.

\section{References}

1. Nadkarni AK. The Indian Materia Medica. Vol II, pp. 101-103. Bombay, India, Popular Book Depot, 1954.

2. Bentley R, Trimen H. Medicinal Plants 3, Andrographis paniculata. p. 197. London, J \& A Churchill, New Burlington Street, 1983.

3. Gupta S, Chudhary MA, Yadav JNS, Srivastava V, Tandon JS. Antidiarrhoeal activity of diterpenes of Andrographis, 1990.

4. Aminuddin, Girach RD, Wasiuddin D. Medicinal potential of Andrographis paniculata (Bhuineem), a less known medicinal plant in Unani medicine. Hamdard Medicus, 1997, 40: 55-58.

5. Joselin J, Jeeva S. Andrographis paniculata: A Review of its Traditional Uses, Phytochemistry and Pharmacology. Med Aromat Plants, 2014, 3: 169. 
6. Akbar S. Andrographis paniculata: A review of pharmacological activities and clinical effects. Alt. Med. Rev., 2011, 16(1): 66-77.

7. Deng WL, Nie RJ, Liu JY. Comparison of pharmacological effect of four andrographolidess. Chinese Pharmaceutical Bulletin, 1982, 17: 195-198.

8. Bensky D, Gamble A. Chinese herbal medicine: Materia Medica. Eastland, Seattle, 1993.

9. Ahmad M, Asmawi MZ. Some pharmacological effects of aqueous extract of Andrographis paniculata Nees. The International conference on the use of traditional medicine and other natural products in health-care (Abstracts), University Sains Malaysia; 1993,122.

10. Zhang CY, Tan BK. Hypotensive activity of aqueous extract of Andrographis paniculata in rats. Clin Exp Pharmacol Physiol, 1996, 23: 675-678.

11. Chander R, Srivastava V, Tandon JS, Kapoor NK. Antihepatotoxic activity of diterpenes of Andrographis paniculata (Kal-megh) against Plasmodium berghei induced hepatic damage in Mastomys natalensis. Int J Pharmacog., 1995, 33: 135-138.

12. Choudhury BR, Haque SJ, Poddar MK, In vivo and in vitro effects of kalmegh (Andrographis paniculata) extract and andrographolide on hepatic microsomal drug metabolizing enzymes. Planta Med., 1987, 53: 135-140.

13. Handa SS, Sharma A, Chakraborti KK. Natural products and plants as liver protecting drugs. Fitoterapia LVII, 1986, 347-351.

14. Chaudhri RD, In: Herbal Drugs Industry. 1st ed. pp. 86, 214-215, 424. Eastern Publ., New Delhi, India, 1996.

15. Harborne JB. Phytochemical Methods, A Guide to Modern Techniques of Plant Analysis, $3^{\text {rd }}$ Ed., Springer (India) Pvt. Ltd., New Delhi, 1991, 5-12.

16. Khandelwal KR. "Practical Pharmacognosy", 2009, 19thEd., Nirali Prakashan, Pune, 149-156 Chase CR, Pratt RJ: Fluorescence of powdered vegetable drugs with particular reference to development of a system of identification. J Amer Pharm Assoc., 2002; 38:324-331.

17. Slinkard K, Singleton VL. Total phenol analysis: automation and comparison with manual methods. Am J Enol Vitic.1977, 28:49-55.

18. Chang CC, Yang MH, Wen HM, Chern JC. Estimation of total flavonoid content in propolis by two complementary colorimetric methods. J Food Drug Anal. 2002, 10:178-82.

19. Oyaizu M. Studies on products of browning reactions: antioxidative activities of products of browning reaction prepared from glucosamine. Japanese Journal of Nutrition, 1986, 44:307-315.

20. Braca A, Sortino C, Politi M. Antioxidant activity of flavonoids from Licanialicaniaeflora. J Ethnopharmacol. 2012, 79:379-81.

21. Ruch RJ, Cheng SJ, Klaunig JE. Prevention of cytotoxicity and inhibition of intracellular communication by antioxidant catechins isolated from Chinese green tea. Carcinogenesis, 1989,10:1003-8.

22. Sakat S, Juvekar AR, Gambhire MN. In vitro antioxidant and anti-inflammatory activity of methanol extract of Oxalis corniculata Linn. Int J Pharm Pharmacol Sci.,2010, 2:146-55.

23. Azeem AK, Dilip C,Prasanth SS, Junise V,Hanan S. Anti-inflammatory activity of the glandular extracts of Thunnusala longa. Asia Pac J Med., 2010, 3:412-20.

24. Edwards CA, Burn NA, Craigne L, Daavidson P, Tomlin J, Sugden K, Johnson IT. Viscosity of food gums determined in vitro related to their hypoglycemic actions, Am. J. Clin. Nutr., 1987, 46, $72-77$.

25. Iain L, Suryana, N, Lukulay P,Marcus I. Determination of chlorophyll a and b by simultaneous multicomponent spectrophotometry. Fresenius' J. of Anal. Chem, 1995, 352: 456-460.

26. Sukran D, Tohit G, Ridvan S. Spectrophotometric Determination of Chlorophyll - A, B and Total Carotenoid Contents of Some Algae Species Using Different solvent. Tr. J. of Botany, 1998, 22: 13-17.

27. Puri A, Saxena RP, Saxena KC. Immunostimulant agents from Andrographis paniculata. J Nat Prod., 1993, 56: 995-999.

28. Chander R, Srivastava V, Tandon JS, Kapoor NK,.Antihepatotoxic activity of diterpenes of Andrographis paniculata (Kal-megh) against Plasmodium berghei induced hepatic damage in Mastomys natalensis. Int J Pharmacog., 1995, 33: 135-138. 
29. Alisha, Myrene RD, Ningthoujam S. Pharmacognostical overview on Terminalia arjuna: A justification of folkloric belief. International Journal of Pharmaceutical Sciences and Research, 2018, 9(12): 100013.

30. Ningthoujam S, Myrene RD, Alisha. Pharmacological evaluation of Parkia speciosa Hassk. for antioxidant, anti-inflammatory, anti-diabetic and antimicrobial activities in vitro, International Journal of Lifesciences, 2018, Special Issue, A11: 49-59.

31. Ashmita M, Myrene RD, Bhat V. Evaluation of pharmacological activities of seed and pericarp of Litchi chinensis Sonn. International Journal of Engineering \& Scientific Research, 2018, 6 (1), 25-35.

32. Sadik CD, Sies H, Schewe T. Inhibition of 15-lipoxygenases by flavonoids: structure-activity relations and mode of action. Biochemical Pharmacology, 2003, 65(5): 773-81.

33. Sanchez-Moreno C. Review: Methods used to evaluate the free radical scavenging activity in foods and biological systems. Food Sci Tech Int. 2002, 8:121-137.

34. T Osawa, Novel natural antioxidants for utilization in food and biological systems, Post harvest biochemistry of plant food materials in the tropics, Japan Scientific Societies Press, Tokyo, Japan, 1994, 241- 251.

35. Fadila MB, Sabiha K, Khalida B, Mohamed C, SandrineA, Yves C, Henry M, Dominique LM. Antioxidant activities of alkaloid extracts of two Algerian species of Fumaria, Fumaria capreolata and Fumaria bastardii, Rec. Nat. Prod., 2007, 1(2-3), 28-35.

36. Wagner EH, Austin B, Korff VM. Organizing Care For Patients with Chronic Illness, Milbank Q., 1996, 74(4): 511-544.

37. Mizushima Y, Kobayashi M. Interaction of anti-inflammatory drugs with serum proteins, especially with some biologically active proteins, J. Pharm. Pharmacol., 1968, 20(3), 169-173.

38. Anosike CA, Obidoa O, Ezeanyika LU. Membrane stabilization as a mechanism of the antiinflammatory activity of methanol extract of garden egg (Solanum aethiopicum). DARU J Pharm Sci., 2012, 20:20-76.

39. Akinpelu BA, Oyedapo OO, Iwalewa EO, Shode F. Biochemical and histological profile of Toxicity Induced by saponin fractions of Erythrophleum suaveolens (Guill. \& Perri) Bark extract. Phytopharmacology, 2012, 3: 38-53.

40. Mandal A, Das K, Nandi DK. In vitro bioactivity study of bark extract of Terminalia arjuna on probiotics, commercially available probiotic formulation. International Journal of Phytopharmacology, 2010, 1(2):109-113.

41. Debnath $\mathrm{S}$ et al. Antibacterial and antifungal activity of Terminalia arjuna Wight \& Arn. bark against multi-drug resistant clinical isolates. Journal of Coastal Life Medicine, 2013, 1(4): 315-321.

42. Yamamoto N, Ueda M, Sato T, Kawasaki K, Sawada K, Kawabata K, Ashida H. et al. Measurement of glucose uptake in cultured cells. Current Protocols in Pharmacology. ed. SJ. Enna Chapter. 2011, 12(12):11-22.

43. Afifi AF, Kamel EM, Khalil AA, Foaad MA, Fawziand EM, Houseny M. et al Purification and characterization of a-amylase from penicillium olsonii under the effect of some antioxidant vitamins. Global Journal of Biotechnology and Biochemistry, 2008, 3(1):14-12.

44. Kwon O, Eck P, Chen S, Corpe CP, Lee JH, Kruhlak M, et al. Inhibition of the intestinal glucose transporter GLUT2 by flavonoids. FASEB J. 2007, 21:366-77.

45. Jadhao D and Thorat B. Purification (crystallization) of bioactive ingredient andgrographolide from Andrographis paniculata. World Journal of Pharmacy and Pharmaceutical Sciences, 2014, 3 (10); 747763.

46. Puri A, Saxena RP, Saxena KC. Immunostimulant agents from Andrographis paniculata. J Nat Prod., 1993, 56: 995-999.

47. Chander R, Srivastava V, Tandon JS, Kapoor NK. Antihepatotoxic activity of diterpenes of Andrographis paniculata (Kal-megh) against Plasmodium berghei induced hepatic damage in Mastomys natalensis. Int J Pharmacog., 1995, 33: 135-138.

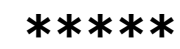

